\title{
Analysis of the Container Dwell Time at Container Terminal by Using Simulation Modelling
}

\author{
Radifan Hassan ${ }^{1}$, Raja Oloan Saut Gurning ${ }^{2}$, Dhimas Widhi Handani ${ }^{3}$ \\ (Received: 06 August 2019 / Revised: 02 December 2019 / Accepted: 06 December 2019)
}

\begin{abstract}
DT). The more least the DT the more efficient a container terminal would be. As the government regulations of the Ministry of Transportation that stated in Number PM 25 in 2017 in Article 2 Paragraph 1 explains that the maximum dwell time must not exceed than 3 days. The purpose of this study is to identify the major factor of prolonged DT in a container terminal. The authors used discrete event simulation to model the system inside the container terminal operation by using Arena Simulation software. The Root Cause Analysis (RCA) is being used for the data analysis and finding the root cause. The container handling inside the container terminal data is collected, then the effect container of handling the equipment on dwelling time was testified by creating a model then analyzed. The result of the simulation is that there is a small impact from container handling equipment towards DT. From the Problem Tree framework that created based on the operational data and interviews. It shows that the most DT is contributed by the prolonged time of container stay at container yard.
\end{abstract}

Keywords—arena, container, dwell time, import.

\section{INTRODUCTION}

P ort in Indonesia plays a significant role in economic development as it affects the national and international logistical distribution. Nowadays, Port is not only as of the gateway of cargoes but also turned to be the logistic hub [1]. Economic development has a connection to the global trade, which facilitated by the increasing process of containerization of freight [2]. The fact that container terminal has a crucial function, in which as an interface point of sea and hinterlands, indicates that its quality of productions and services cannot be neglected [3]. According to the World Bank, container throughput in Indonesia has increased from 2010 until 2017 with the annual growth rate of $5.3 \%$. the container port traffic in Indonesia in 2010 was 9,692,442 TEUs and it has been increased into 13,859,500 TEUs in 2017 [4].

One of the parameters that are used to calculate the efficiency of the container terminal, as the main reference in the port is import container dwelling time. Dwelling time is the amount of time that an import container sits at a marine terminal (terminal dwell time) or rail terminal (rail dwell time) before commencing its inland journey [5]. So that container dwelling time means the time required from the start lifted the containers from the vessel until the container out of the port. The prolonged dwell time at a port may result in negative effects. According to [6] dwell time will

Radifan Hassan, Marine Engineering Department, Faculty of Marine Technology, Institut Teknologi Sepuluh Nopember, Surabaya, 60111, Indonesia. E-mail: hassanradifan@gmail.com

Raja Oloan Saut Gurning, Marine Engineering Department, Faculty of Marine Technology, Institut Teknologi Sepuluh Nopember, Surabaya, 60111, Indonesia. E-mail: sautgurning2@gmail.com

Dhimas Widhi Handani, Marine Engineering Department, Faculty of Marine Technology, Institut Teknologi Sepuluh Nopember, Surabaya, 60111, Indonesia. E-mail: dhimas_mareng@yahoo.com directly affect operational costs in the ports as it increases inventory levels and uncertainty in the dispatching process. On the other hand, dwell times have been identified as an element for the competitiveness of the port and a factor in port choice related decisions [7]. Moreover, from the perspective of the shippers, decreasing port dwell times is one of the main goals in the port supply chain [8].

Per 2018 the import dwelling time in a container terminal that the authors make the place to research on has the number of 5.08 days. If this number be compared with the other countries such as Singapore in which has dwelling time of 1.5 days, Hong Kong has dwelling time of 2 days, France has a dwelling time of 3 days, Los Angeles has a dwelling time of 4 days, Australia has dwelling time of 3 days, Port Klang, Malaysia has a dwelling time of 4 days, and Leam Chabang, Thailand has a dwelling time of 5 days [9]. Prolonged dwelling time will affect to the increment of Yard Occupancy Ratio (YOR), and it will be resulting in no land for the container to be stacked from the berthing ship [10]. As dwelling time increased, then the logistical cost will increase as well.

As dwelling time has a significant effect on the efficiency of the port then the analysis in reducing dwelling time must be conducted. Inadequate port capacity and navigational aids, bunching of vessels, limited cargo handling facilities, high downtime of equipment, low labor productivity and shortage of storage space, those factors contribute to the how long dwelling time will occur [11]. Dwelling time also has a relation to the technical aspect in which the tools that are used in the terminal itself, including cranes and trucks [12]. This study will focus on the import container dwell time. The purpose of this study is to identify the factor of prolonged dwell time in the container terminal in the unloading equipment and the other operational aspect. 


\section{LITERATURE REVIEW}

\section{A. Container Terminal}

Container Terminal is a modal transfer (interface) land transport to unload the containers from the vessel then transported through the land transportation until it is brought out pier gate [12]. When the ship arrives at the container terminal, the import containers need to be unloaded from the ship.

\section{B. Dwelling Time}

Port terminal capacity has the definition as the amount of cargo that can be handled by a port per time period [13]. As the number if stacking containers is estimated as a function of container dwell times, and other factors such as storage capacity at the yard [14]. Container dwell time measures the total time spent on removing containers, from the time a vessel arrives in port to the point when the container leaves the port premises [4].

\section{Research Study Location: Container Terminal in Surabaya, Indonesia}

Marine container terminal, Surabaya Container Terminal or PT Surabaya Container Terminal has contributed significantly to support Port of Tanjung Perak is the second busiest port in Indonesia. PT Pelabuhan Indonesia III (PELINDO III) or also known as the Indonesian Port Corporation has reported in their annual report that Surabaya Container Terminal has created growth for the container throughput. It is recorded that in 2018 container terminal in TPS has the number of 1,464,258 TEUs, where it gives a significant increment that is $5.67 \%$ compared to 2017 's container throughput where it has the number of $1,385,689$ TEUs. This growth also increased $6 \%$ from the target that has been set at the beginning of the year of 2018 in which $1,381,315$ TEUs.

To support the operational activity inside the terminal, this marine container terminal has two docks including the domestic and international dock. The domestic dock has a length of $450 \mathrm{~m}$, the width of $45 \mathrm{~m}$ and $7.5 \mathrm{~m} \mathrm{LWS}$ for the water depth. Meanwhile, the international dock has the length of $1000 \mathrm{~m}$, the width of $50 \mathrm{~m}$, and $10.5 \mathrm{~m}$ LWS for the water depth. Besides, TPS has been equipped with a sort of facilities in handling containers including cranes. The type of cranes that available are Rubber Tyred Gantry Crane, Harbour Mobile Crane, and Ship-to-Shore Crane. Other facilities in handling containers including 75 unit of truck and 6 unit of reach stacker. Marine container terminal Surabaya Container Terminal also has adequate infrastructure in storing containers with the $45 \mathrm{Ha}$ of Container Yard and $1 \mathrm{Ha}$ of Container Freight Station.

\section{Container Terminal's Performances}

The ability and speed of the implementation of cargo goods handling can be achieved from the activities of unloading cargo from the ship to the warehouse or stacking field or vice versa [15]. Several factors could be carried by calculating goods service performance:

1) Unloading Time

$$
t_{\text {unloading }}=t_{\text {unloading }}+t_{\text {preparation }}+t_{\text {delay }}
$$

2) Box/Crane/Hour

Productivity of a crane can be defined by Box/Crane/Hour $(\mathrm{B} / \mathrm{C} / \mathrm{H})$ where it is the amount of charge in a box that is able to be moved by one unloading device or crane within one hour.

$$
B / C / H=\frac{\text { TotalMoves }}{\text { WorkingTime }}
$$

3) Container Yard Occupancy Ratio (CYOR)

$$
C Y O R=\frac{T E U s \times \text { Days }}{\text { CYcapacity } \times \text { dayinayear }}
$$

There also the calculation for container yard annual capacity developed by [16]:

$$
\begin{aligned}
& \text { ContainerYardArea }=\frac{C s \times H \times W \times K}{T \times F} \\
& \mathrm{Cs}=\text { the number of container ground slot (TEU) } \\
& \mathrm{H}=\text { the mean profile height } \\
& \mathrm{W}=\text { the working slots (TEUs) in the container } \\
& \text { storage }(0.8-0.9) \\
& \mathrm{T}=\text { the mean dwell time (day) } \\
& \mathrm{F}=\text { the peaking factor (approximately } 20 \\
& \text { percent) }
\end{aligned}
$$

\section{METHOD}

Simulation modeling is used in this study. The model is a result of interpretation of a real system consists of logic combination and mathematics that considers. Those factors are influenced by the problem beforehand. The model itself must be done carefully and in detail, in order for the simulation model that obtained have a least different with the real one. In order to create a good model, the criteria are easy to understand, having clear objectives, contains clear problem solving, and easy to be controlled and manipulated by model users.

Modeling is the process of producing a model that is a representation of the structure and system that works. Verification and validation also need to be done to find out that the model made has no different from the real system. Verification is the process of checking the data of whether the operational logic of the model is in suitability with the logic of the flow chart. Verification needed to check the translation of conceptual models into programming languages correctly [17]. On the other hand, validation is the determination process of whether the model that has been made is in accordance with the real system that is modeled [17].

Discrete systems are state variables which only change at the set point. The model of this system exists when the state variable changes in a discrete-time set. Discrete event simulations regarding system modeling 
are events that exceed representative time where state variables change instantly and separately per time point.

\section{A. Input Parameter}

The author will focus on the import container operational flow. The international dock has the length of $1,000 \mathrm{~m}$, a width of $50 \mathrm{~m}$ and $-13.5 \mathrm{~m}$ LWS for the water depth. Marine container terminal Surabaya Container Terminal also has adequate infrastructure in storing containers with the $45 \mathrm{Ha}$ of Container Yard and 1 Ha of Container Freight Station.

Surabaya Container Terminal has the number 9 blocks at the yards in import international which each block is served by the RTG, while each block has $50-80$ slots and 4 tiers. With the number of trucks are 81 , it has the function to transport container from the wharf to the container yard and vice versa. The summary of the facility inside the container terminal is shown in Table 1. And the allocation of quay crane is shown in Table 2.

TABLE 1.

QUAY CRANE ALLOCATION AT INTERNATIONAL WHARF

\begin{tabular}{cc}
\hline Variable & Unit \\
\hline Ship to Shore Crane & 15 \\
Rubber Tyred Gantry & 30 \\
Reach Stacker & 6 \\
Truck & 81 \\
Number of International Berth & 5 \\
International Container Yard (TEUs) & 32,223 \\
\hline
\end{tabular}

TABLE 2.

QUAY CRANE ALLOCATION AT INTERNATIONAL WHARF

\begin{tabular}{ccccc}
\multicolumn{5}{c}{ QUAY CRANE ALLOCATION AT INTERNATIONAL WHARF } \\
\hline Berth & 1 & 2 & 3 & 4 \\
\hline Number of QC & 3 & 4 & 3 & 3 \\
\hline
\end{tabular}

TABLE 3.

\begin{tabular}{ccc}
\multicolumn{3}{c}{ VESSEL INTER-ARRIVAL DISTRIBUTION } \\
\hline Vessel & Inter-Arrival & LOA \\
\hline CSCL & $169+3.53 \mathrm{e}+003 * \mathrm{BETA}(0.0446$, & 200 \\
SIAB & $154+\operatorname{WEIB}(27.9,0.443)$ & 176 \\
KOJA & $162+\operatorname{WEIB}(106,0.245)$ & 193 \\
NAAM & $848+\operatorname{GAMM}(2.18 \mathrm{e}+003,0.28)$ & 261 \\
STOL & $495+\operatorname{WEIB}(65.8,0.292)$ & 168 \\
PORT & $641+\operatorname{WEIB}(149,0.383)$ & 200 \\
SEDA & $221+\operatorname{WEIB}(268,0.518)$ & 116 \\
MSIM & $193+819 * \operatorname{BETA}(0.32,0.849)$ & 201 \\
OLIV & $510+\operatorname{WEIB}(157,0.596)$ & 216 \\
LALA & $658+\operatorname{WEIB}(214,0.283)$ & 216 \\
\hline
\end{tabular}

In this model, the variable that will be changed is the amount of operated crane. There are also several vessels that will be used to be the sample of this model. The type of distribution and the parameter values are associated with each vessel, as these vessels have different sizes and schedules and, thus, carry a different quantity of containers in box.

We collected data on the inter-arrival time of ships then these data were then fitted into theoretical fitting distribution. The summary of these data is shown in Table 3. While Table 4. is the summary of the fitting distribution of the available resources.

Figure 1. is the flow chart that is used as the basis to create the simulation model in the ARENA Software. As the flow will starts at the Ship Arrival, Berthing Process,
Unloading Process by the quay crane, Truck Transport, Rubber Tyred Gantry (RTG) stacking, Customs Process, then finished with Job Delivery then the container leaves the port as it reaches the Port Gate.

\section{B. Verification and Validation}

In order to ensure that the model built is in accordance with the characteristics of the real system and the results of the simulation have a level of accuracy that is acceptable, the model must be verified and validated [19]. Verification is examining the translation of conceptual simulation models (flow diagrams, constraints, and assumptions) into the programming language correctly, aiming to ensure that the model that has been created can be run [17]. While validation aims 
to ensure that the model is in accordance with existing real conditions [17]. The interval estimates will be used in the process of replication and its validation.

Verification is proceeded by checking the animation, using a model of sanity checks in the software verification and checking the performance at each process. Validation includes comparing between all the result at each of the process and the real system then it will be compared with the real total dwelling time that occurred in the Surabaya Container Terminal. In this simulation, the length of the simulation run is set at 365 days (12 months) and each experimental cell is replicated five times. It was proved that there was no statistical difference between the dwelling time of the empirical data and the dwelling time of the simulation results.

TABLE 4.

\begin{tabular}{ccc}
\multicolumn{3}{c}{ RESOURCES FITTING DISTRIBUTION } \\
\hline Type of Data & Distribution & Unit \\
\hline Vessel Berthing Time & $-0.5+\operatorname{GAMM}(11.4,1.13)$ & Hours \\
Quay Crane Delay & $-0.001+\operatorname{GAMM}(1.47$, & Hours \\
& $0.796)$ & \\
Quay Crane Hours per Box & $0.01+0.03 * \operatorname{BETA}(5.26$, & Hours \\
& $3.49)$ & per Box \\
RTG Handling (Stack) & $0.01+\operatorname{GAMM}(0.00356$, & Hour per \\
& $9.39)$ & Box \\
Container Stay at CY & $\operatorname{NORM}(52.1,13.3)$ & Hours \\
Customs Clearance & $16+15 * \operatorname{BETA}(1.32,1.26)$ & Hours \\
Job Delivery Request & $\operatorname{NORM}(24.4,2.46)$ & Hours \\
Truck Gate-In to CY & $\operatorname{NORM}(34.1,5.77)$ & Minutes \\
Truck from CY to Gate-Out & $\operatorname{NORM}(31.2,16.1)$ & Minutes \\
\hline
\end{tabular}

\section{Root Cause Analysis (RCA)}

In choosing an RCA framework, the comprehensiveness, academic citations, and availability must put into concern. Based on that, this study chose to follow the seven-step RCA process proposed by [18]. The steps in this framework is showed in Figure 1 Each step consists of a set of tools to produce the results needed, whereas the seventh step is outside the scope of this study.

1) Problem Understanding. The goal of this step is to understand the problem and prioritize the issues. The field observation and interviews are used to have a better understanding of the issues.

2) Problem Cause - Brainstorming. The goal of this step is to cover other possible issues that may have to cause the problem. On this step, the unstructured Brainstorming, which is a technique where the verbally suggested all possible causes they could think of by an open-ended question, which the results of these will be noted and summarized.

3) Problem Cause Data Collection - Data Analysis \& Interviews. This study will use the primary data in which the breakdown data of dwelling time inside container terminal. From the primary data, the author will only focus on the major problem to make a mutually exclusive and completely exhaustive problem identification. And secondary data in which interviews as the data collection approach as the study required an in-depth understanding of the root problem of the dwelling time. The interviews were conducted in a face-to-face and were designed with open-ended interview questions for sharing knowledge about the problem. The interview subjects were focusing on the stakeholders who directly involved in the container terminal operations.

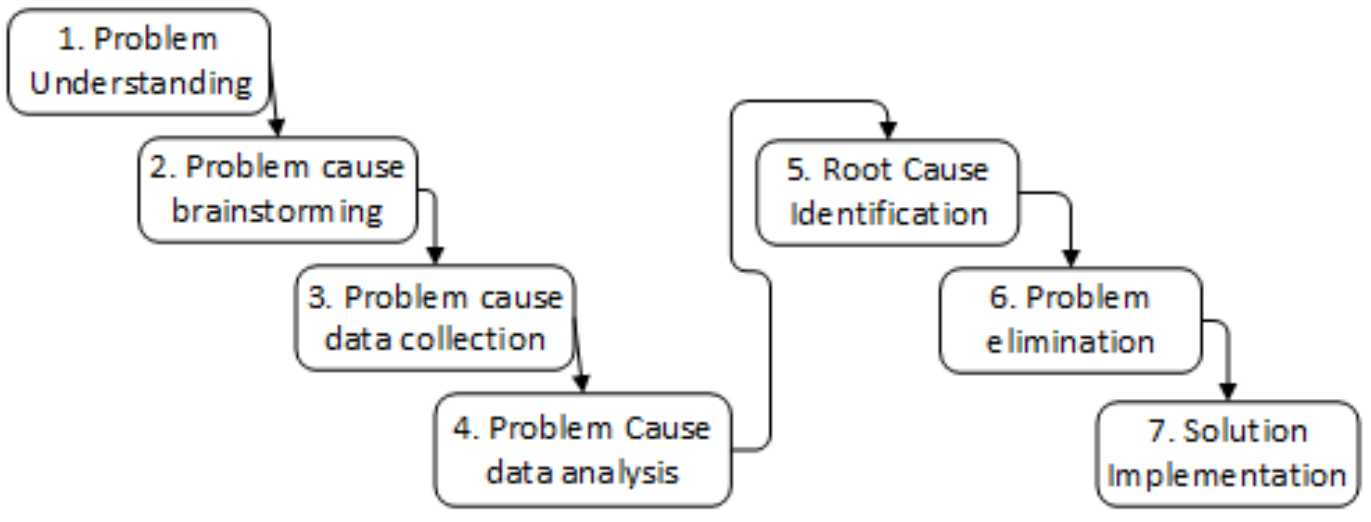

Figure. 1. Seven Step of RCA [19].

4) Problem Cause Data Analysis. For Descriptive analysis of continuous type questions, the author applied the median as the primary measure of central tendency. The IBM SPSS software then will be used 
for the statistical analysis. The questionnaire had several open-ended questions which the answers are treated by listing and categorizing the responses. The Bivariate analysis is proceeded to do the analysis of analyzing the questions. The author used Pearson two-tailed Correlation test to reveal relationships between pairs the variable as this test does not assume normality in the sample

5) Root Cause Identification. The goal of this step is to discover the root cause(s) of the problem. At this step, the author applied the Problem Tree [20]. as showed in Figure 2 which is a tool for identifying the causes of a big problem, together with the causes/factors influencing the problem. The results from this process should map to the problem.

6) Problem Elimination. The end goal of this step is to offer solutions to deal with the root causes of the problem. According to Andersen and Fagerhaug, the primary two types of tools for drafting treatments; first, design the solution to stimulate creativity for new solutions, second, is designed for developing solutions.

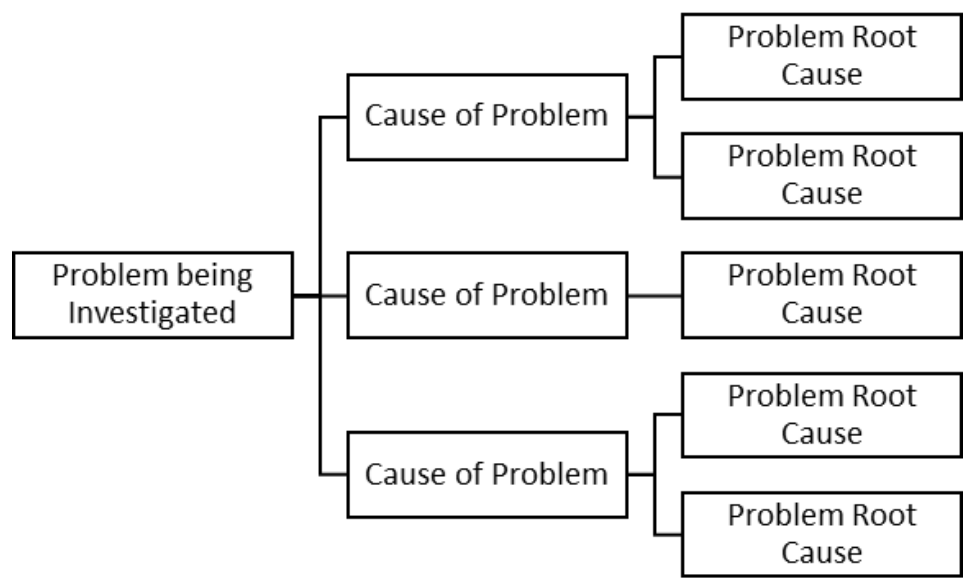

Figure. 2. Problem Tree [20]

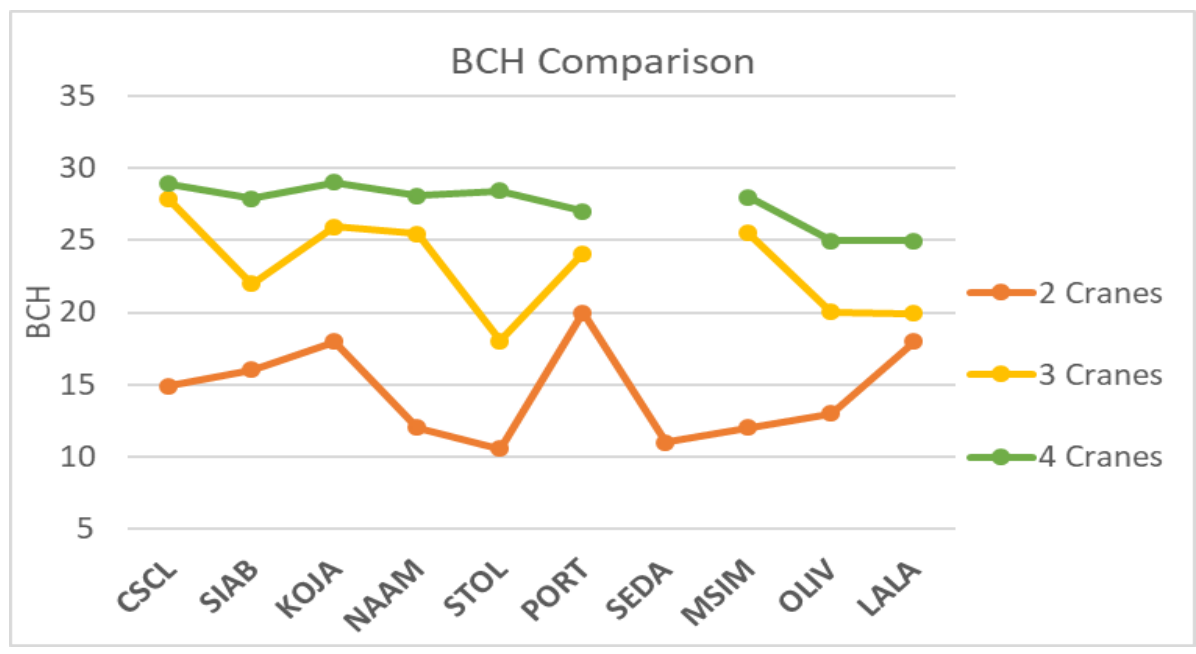

Figure. 3. BCH Comparison.

\section{RESULT AND DISCUSSION}

\section{A. Hypothesis Testing}

1) Handling Time

Surabaya Container Terminal has 13 of quay cranes and 4 berths in the international docks. In which the distribution of cranes is between 3-4 cranes for each berth. The input of crane in the simulation is between 2-4 and the simulation result will describe the $\mathrm{BCH}$ of each vessel in discharging the containers.

From this simulation, the comparison between the results are showed from Figure 3 that the difference if 3 cranes are utilized the increment of $\mathrm{BCH}$ would be $21.73 \%$ in average or $23.85 \mathrm{BCH}$ and if 4 cranes are utilized the increment of $\mathrm{BCH}$ would be $35.33 \%$ in average or $28.48 \mathrm{BCH}$.

From the simulation results, it found that the containers shifted into the Surabaya Container Terminal equal to 104,166 boxes which represent 365 days of real-time. Table 8 describes the difference in throughput volume in box on various cranes utilized. It showed from Table 5 that the increase of throughput if 3 cranes utilized is equal to $21.73 \%$ or 133,083 boxes and if 4 cranes 
utilized the increase is equal to $35.33 \%$ or 161,070 boxes.

2) Handling Time Contribution to Dwell Time

As the handling time inside the terminal has been run in the simulation, then it will be compared to the total dwell time that happened in the Surabaya Container Terminal. Figure 4 showed that the dwell time can be decreased by crane utilization. It resulted that the average dwell time can be decreased as $0.023 \%$ if 3 QCs utilized and the decrement of $0.029 \%$ can be achieved if 4 QCs utilized from 2 cranes utilized. But, the utilization of crane can't be implemented in all ships. SEDA vessel is a vessel with the length of $116 \mathrm{~m}$ where the 2 number of cranes is already optimized because of the constraint of the ship length and the number of containers brought. So, it can be concluded that the optimization of the number of cranes may decrease the dwell time, but it can be implemented on all type of ship length.

TABLE 5.

BOX VOLUME COMPARISON

\begin{tabular}{cccc}
\hline & 2 Cranes Utilized & 3 Cranes Utilized & 4 Cranes Utilized \\
\cline { 2 - 4 } Vessel & Boxes Throughput & Boxes Throughput & Boxes Throughput \\
\hline CSCL & 15,184 & 16,689 & 18,410 \\
SIAB & 50,662 & 64,864 & 78,683 \\
KOJA & 5,656 & 6,462 & 8,888 \\
NAAM & 3,474 & 7,527 & 8,369 \\
STOL & 2,912 & 3,744 & 9,568 \\
PORT & 4,284 & 4,428 & 4,692 \\
SEDA & 750 & 750 & 750 \\
MSIM & 14,007 & 19,338 & 20,769 \\
OLIV & 6,302 & 6,850 & 7,388 \\
LALA & 935 & 2,431 & 3,553 \\
\hline
\end{tabular}

Dwell Time Crane Verieties Comparison

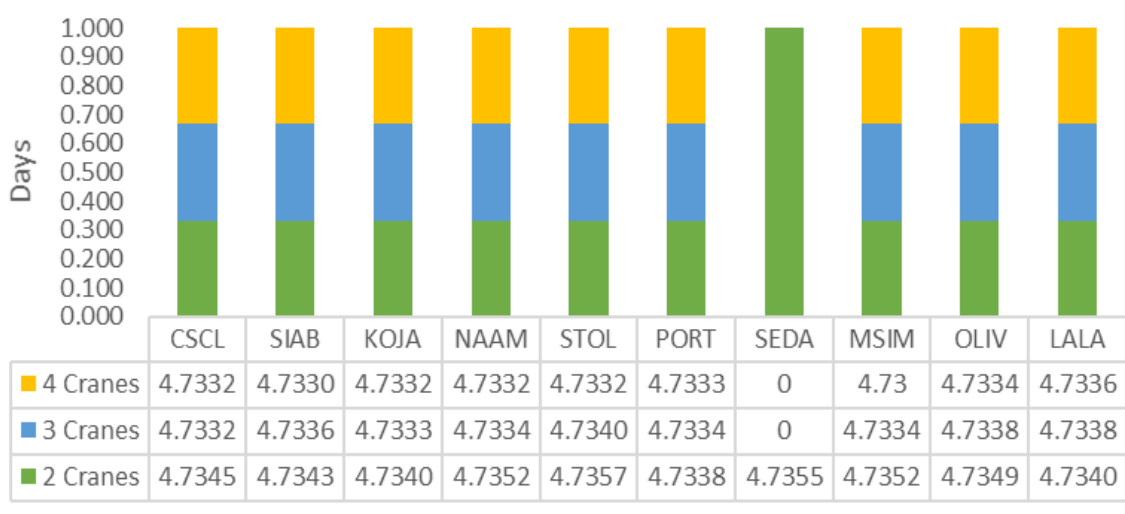

Figure. 4. Dwell Time Comparison.

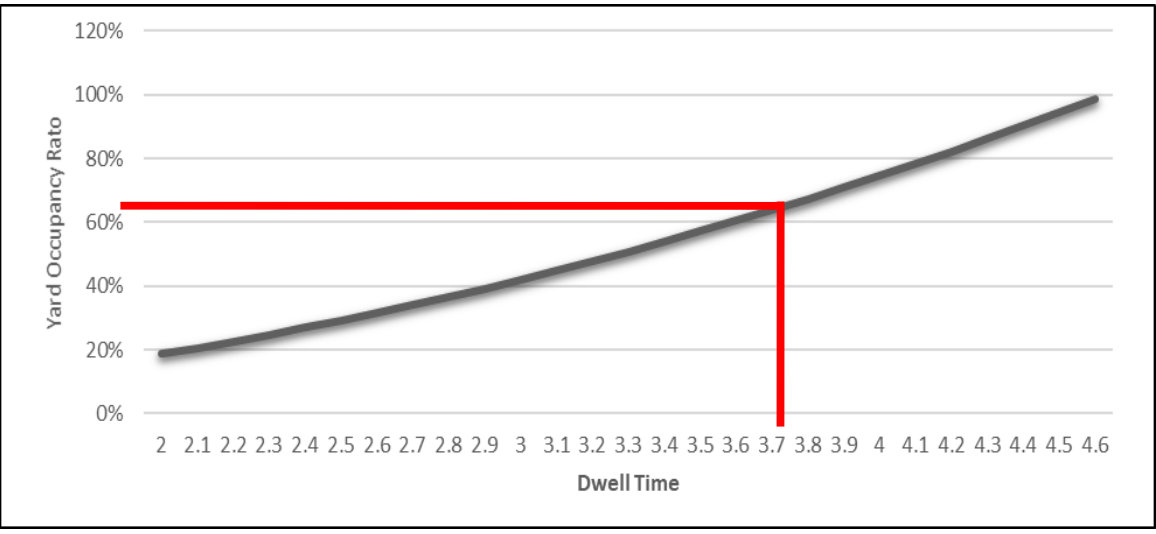

Figure. 5. YOR and Dwell Time Correlation. 
3) Dwell Time Analysis, Yard Occupancy Ratio and Yard Capacity

The analysis will focus on the yearly throughput where the throughput that will be used is the import throughput from 2018 with the number of 1,464,258 and the yard capacity that will be used is the capacity of the yard in $100 \%$ or $3,171,785$ TEUs. The average of dwell time in Surabaya Container Terminal in 2018 is 5.08 days.

From the information gathered from PT Terminal Petikemas, if the YOR has outreach the number of $65 \%$, the container terminal will propose a terminal development initiative or overbrengen terminal. The development has a purpose to maintain the good performance of the terminal operation. Figure 5 is describing the calculation of YOR that correlate to the assumption of dwell time in Surabaya Container Terminal.

It showed from Figure 5 That the ideal dwell time in Surabaya Container Terminal is below 3.7 days. As if the dwell time has exceeded 3.7 days then it will outreach the YOR of $65 \%$ and the container terminal need to consider about container yard terminal development.

\section{B. Root Cause Analysis}

1) Step $1 \& 2$ - Problem Understanding and Cause Brainstorming

The goal of these steps is to scope the RCA and center on the preliminarily identified problem causes. These have been done at the previous sub-part where the initial idea was the container handling in which the container crane process contributes to the dwell time significantly. But in the simulation, it is found that the scenario of container crane handling only may decrease the dwelling time up to $0.029 \%$.

\section{Step 3 - Data Collection}

Identification of detailed dwell time inside the container terminal is obtained by conducting field surveys, direct interviews with employees and data analysis that the data is provided by the PT Terminal Petimekas Surabaya of the 2018 operation. From those resources then the data can be broken down into smaller components so that the most dwell time can be discovered. The quantitative data provided by the Terminal Petimekas Surabaya then will be applied to the ARENA Software to simulate the real condition of container terminal operation. This simulation is representing the real condition, run for 365 days throughout 2018, and be made for 5 replications with 5\% maximum of error.

\section{Step 4.1 - Problem Cause Data Analysis: Container Terminal Data Analysis}

At this step, the breakdown data is made into the sequel of the process so that the better understanding will be cleared out. Figure 8 tells about the sequel of the dwell time and the dwell time contribution on each of process in the operational activity that happens in Surabaya Container Terminal. As the definition from [4], the dwell time starts from the time a vessel arrives in port to the point when the container leaves the port premises. So that the dwell time in Surabaya Container Terminal starts from the berthing process then it continues to several components. Crane delay also contributes to dwell time when it includes the time spent in crane breakdown, QC clash, and lashing. Then the dwell time continues to the quay crane unload the containers, then truck transport from the berth until the container yard and handled by the RTG. then the container continues to the second biggest dwell time, custom process, where it contributes $20.85 \%$ to dwell time. As the customs clearance has been done, the job delivery will be made. Then the container still stays at the container yard as of haven't taken by the consignee, where this stay contributes the largest contribution to dwell time with the number of $46.62 \%$. Then if the truck from consignee arrives at the gate in, the truck needs to complete the administration until it will proceed to the container yard to take the container then continue to the administration process before proceeds to the gate out. At the time when the container leaves the port gate with the truck thus the dwell time ended.

As of this data analysis, the author will only focus on the major factor of the dwelling time, in this case, the author focuses on the prolonged stay of the container at the container yard. The in-depth interview has proceeded in order to have a deep understanding of why the container is taking a long time in staying at the container yard.

\section{E. Step 4.2 - Problem Cause Data Analysis: Interviews Data Analysis}

The goal of the interview is to have a deep understanding of the root cause of the problems in the prolonged dwelling time because of container stay at container yard. The author uses the categorical analysis in doing the interview, which are the position of the stakeholders and the length time of work. The authors interviewed thirty people at the container terminal. The interview subjects to the Management of Surabaya Container Terminal, External Contractors, Custom Officers and Representative from Customer.

As the secondary data collected from the Surabaya Container Terminal, the most dwell time caused by container stay at the container yard. At this interview, the prolonged stay of container stay at $\mathrm{CY}$ is a variable. The author derived four topics to be asked to the participants: (i) basic knowledge of dwelling time, (ii) consignee external factor in leaving the container at CY, (iii) import document related, and (iv) process at the custom lane. As the field observations inside the container terminal and literature, the author has summarized the variable and indicators that resulting in the prolonged container stay at $\mathrm{CY}$ to be asked as a Likert-scale questionnaire.

1) Descriptive Analysis: From the descriptive and the Likert-scale questionnaire analysis, it showed that all respondents know about the basic knowledge of dwelling time inside container terminal. The study also uncovered several uncertainties. where the consignee is leaving the container because of the tariff inside container terminal is far cheaper compared to if they lease a private container 
storehouse. The other reason of consignee leaving the container is that even the consignee has their own warehouse for their goods, their warehouse might be full, and the container terminal is the alternative for them to leaving their goods inside the container terminal. Beside the consignee case, there also a case where it caused the prolonged dwelling time on its import document processing by custom.

2) Qualitative Analysis of Differences Between Groups: Management. This group consists of supporting, the middle and upper level which had all know the basic knowledge of dwelling time. When the author asked about how the container terminal dealing with the dwelling time, they had a similar opinion: the container terminal has an autonomy only on container handling equipment. In which the contribution of container handling process to the dwelling is very small. The most dwelling time caused by customer or consignee, where customer deliberately leaving their container in the container terminal because the tariff of container stay at container terminal is cheaper compared if the customer leases a container storehouse. Another case is that sometimes the customer's goods warehouse is already full so that the container terminal is became their 'warehouse' for their goods. There is an interesting fact where this prolonged container stay at CY basically does not bring disadvantage to the container terminal as the yard occupancy ratio (YOR) is below the standard of PT Terminal Petikemas, in which $65 \%$. Instead, the more time of container stays at container yard the more revenue received by the PT Terminal Petikemas. The Surabaya Container Terminal also applied the progressive tariff where the tariff will be increased as much as $900 \%$ if the container stays at the container terminal on the fourth day and on.

3) External Contractors. Consists of outsourcing employees and operators that have the stake inside the container terminal. It being said that the container terminal only focuses on handling container and it has increased its performance, in this box/crane/hour $(\mathrm{BCH})$ of crane in handling container to be discharged from vessel and the move per hour (MPH) of a container inside the container terminal (the handling process from truck transport, RTG handling, until the container stacked on container yard's block). The rest of the dwelling time proportion is depending on customer and custom.

4) Custom Officers. This group is the one responsible for processing the import document inside the container terminal. When the author asked about why a long time spent in the dwelling time, the responses were the problem is on the red lane. When container on this lane, it required more documents to be completed by the customer. And the custom also facing another problem where there are more documents to be verified by the customs officers and it hampered by the lack of personnel of custom officers and the working hour and business days. Where the working hour only limited from 08:00 AM until 05:00 PM. And the business days, if there are many days off at a month, the process in finishing the documents also hampered. The custom also working faster as the President of the Republic of Indonesia instructed to minimize the dwelling time targeted at the maximum three days through the regulation of Ministry of Transportation. And it proven by the green lane container process is already below the target of this regulation. In facing dwelling time, the custom also provides the temporary container storehouse or Tempat Penimbunan Sementara (TPS) that controlled by the state's custom. Where this container storehouse will be the place for a container if the container stay is more than three days at the container terminal of Surabaya Container Terminal because of unfinished import document process. The movement from the container terminal to the custom's container storehouse is the authority of the state's custom.

5) A representative from Customer. The customer is the one who owns the container and pays the tariff of container stay at the container yard. It was being said that the tariff inside the container terminal is cheaper than a private storehouse. Even if the container stays for more than three days, with the progressive tariff that applied by Surabaya Container Terminal, the customer still considers that they still pay less money for container stay at the container terminal than container stay at the private container storehouse. 


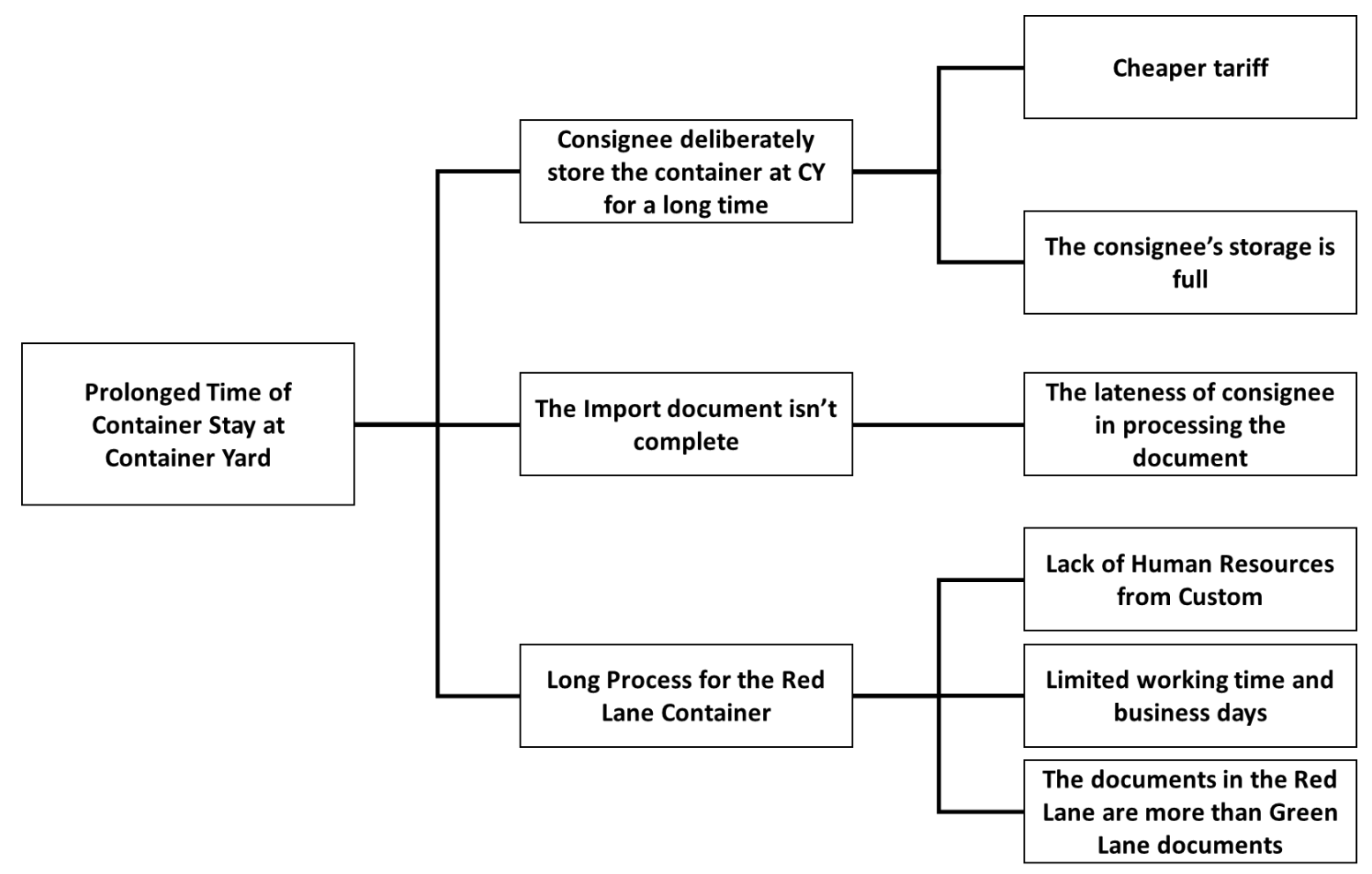

Figure. 6. Problem Tree of Prolonged Time of Container Stay at Container Yard.

\section{F. Step 5-Identified Root Causes}

The major problem of prolonged dwell time inside the Surabaya Container Terminal is the prolonged time of container stay at container yard. Based on interviews with several stakeholders involved in the Surabaya Container Terminal and field observations the Problem Tree is created that is shown in Figure 6. There are several causes that result in prolonged dwell time, especially in container stay at container yard:

1) There are so many containers that have Surat Pemberitahuan Pengeluaran Barang (SPPB), Pemberitahuan Impor Barang (PIB) and Surat Penyerahan Petikemas (SP2) but the containers haven't picked out of container terminal. For several importers, the container yard has intentionally made a place of container yard to store their goods in the containers or made this place as "warehouse" for their interest as the result of cheap rates of terminal stay.

2) The problem of custom documents that haven't completed yet.

3) The problem long processing time of red lane goods by the customs officer.

In dealing with these problems, several steps have been taken by some involved parties, which are:

1) The uncontrolled cumulation of containers may disturb the traffic inside the terminal and this disturbance may be resulting in congestion and stagnation of activities of loading/unloading as well as be handle inside the container terminal. The current condition is that container terminal of Surabaya Container Terminal can't be developed in terms of area. The terminal has taken several steps:

a) The implementation of progressive tariff for container stay for more than 3 days. The progressive tariff will prevail after the third day of container stay and the increment of the tariff is 900\% more expensive than the regular tariff.

b) The Surabaya Container Terminal has built a partnership with "Lini Kedua", a container storehouse as one of the business lines provided by PT PELINDO III. Container that stays more than 3 days then it will be moved into this storehouse in order to maintain the YOR inside container terminal.

2) While the container that stays more than three days that resulted by the incomplete custom documents or red lane container will be taken care of by the custom party. The container will be moved into temporary container storehouse that supervised by the customs officer. The container will remain stay at this temporary storehouse until the required document completed. This movement is fully the responsibility of the state's custom.

\section{CONCLUSION, RECOMMENDATION AND FUTURE RESEARCH}

\section{A. Conclusion}

By conducting the field observations, interview with Surabaya Container Terminal employees, and data analysis for container handling, it can be concluded that from the simulation the quay crane utilization is impacting the time of unloading. 3 quay cranes utilization may increase the crane's $\mathrm{BCH}$ into 23.85 Box/Crane/Hour. 4 quay cranes utilization may increase the crane's BCH into $28.48 \mathrm{Box} / \mathrm{Crane} / \mathrm{Hour}$. The crane's optimization may also increase the box throughput inside 
the terminal. This crane optimization may also decrease the total dwell time by $0.029 \%$.

\section{B. Recommendation}

Based on the research results and data analysis, there are still several things that must be refined to obtain better results in the container terminal operation of Surabaya Container Terminal. These recommendations are being provided to both parties Surabaya Container Terminal and customs elements. The recommendations that can be given by the author are:

1) For PT Terminal Petikemas, the optimization of cranes inside the container must be done as it affects to optimized $\mathrm{BCH}$ of crane and the throughput volume.

2) It is found that the price rate of container stays and its progressive tariff at Surabaya Container Terminal's container yard is far cheaper if it compared if the importer leases the other private container storehouse. So that the increment of the basic and progressive tariff could be implemented. Besides, it may increase the revenue of Surabaya Container Terminal.

3) As the biggest proportion of dwell time is contributed by the container stay at container yard, the better planning of container allocation must be done. The yard planning could be planned by dividing the containers on its day of stay, or types, or consignee destinations. The model simulation can be used to compare the time used between those plans.

4) The container terminal gates, both gate-in and gateout, still using traditional hand-writing administration. So that the implementation of auto gates system inside container terminal must be done by fully digitized the process through E-Document. It seamless the process of the container in and out by digitized the administration process and decrease the consumed time of truck in and out. This system may also be integrated with Inaportnet, a system information system provided by Indonesia's government so that it will support the National Single Window (NSW) program.

\section{Future Research}

There are points that did not cover by the author in this research, thus the future research must be done to make an appropriate research result. Those points are:

1) As the waiting time inside the container terminal can be decreased, there may be cost savings for container terminal and the shipping companies This issue has not been explored in this research and would be an important and interesting topic for future work.

2) The biggest proportion of dwell time has been identified in which in the process of container yard planning. Thus, future research about the simulation of container allocation inside the container yard can be analyzed to find out the least time produced in order to decrease the dwell time.

3) Other research also can be carried in the area of customs process as the customs clearance process also one of the biggest contributors to dwell time.

\section{REFERENCES}

[1] Pettit, S. J. \& Beresford, A. K. C., 2009. Dalam: Port development: from gateways to logistics hubs. s.1.:s.n., p. 37-41.

[2] Takola, D. M., 2018. Analysis of Import Container Dwelling Time in Surabaya Container Terminal (TPS) Port of Tanjung Perak. International Journal of Management and Applied Science.

[3] Syafaaruddin, D. S., 2015. Evaluation of Container Terminal Efficiency Performance in Indonesia : Future Investment. Erasmus University Rotterdam.

[4] World Bank, 2015. Improving Indonesia's Freight Logistics System: A Plan of Action. Dalam: Jakarta: s.n., p. 22

[5] Nicoll, J., 2007. Innovative Approaches to Port Challenges. Norfolk Virginia, s.n

[6] Arvis, J. \& Raballand, G., 2010. The Cost of Being Landlocked Logistics Costs and Supply Chain Reliability. Washington DC, The World Bank.

[7] Magala, M. \& Sammons, A., 2008. A New Approach to Por Choice Modelling. Maritime Economics and Logistics, pp. 10(12): 934.

[8] Lee, T., Park, N. \& Lee, a. D., 2003. A Simulation Study for the Logistics Planning of A Container Terminal in View of SCM. Maritime Policy \& Management, p. 30(3): 243254.

[9] Artakusuma, A., 2012. An Analysis of Import Container Dwelling Time at Port of Jakarta International Container Terminal (JICT) Tanjung Priok. Bandung Institute of Technology.

[10] Fajar, M. R., 2015. Reducing Import Container Dwelling Time Study by Simulation Approach (Study Case : Terminal Petikemas Surabaya). Sepuluh Nopember Institute of Technology.

[11] Dowd, T. \& Leschine, T., 1990. Container Terminal Productivity: a perspective. Maritime Policy \& Management, p. 17(2): 107112.

[12] Haerany, H. \& Adisasmita, S. A., 2017. Handling Containe Terminal Based on Dwelling Time in Macassar. Kuala Lumpur, Malaysia, s.n.

[13] Bassan, S., 2007. Evaluating Seaport Operation and Capacity Analysis-Preliminary Methodology. Maritime Policy \& Management, p. 34(1): 319.

[14] Gaete, M., González-Araya, M. C., González-Ramírez, R. G. \& Astudillo, C., 2017. A Dwell Time-based Container Positioning Decision Support System at a Port Terminal. s.l., Science and Technology Publications, Lda., pp. 128-139.

[15] Budiyanto, E. H. \& Gurning, R. S., 2007. Port Management s.1.:PT. Andhika Prasetya Ekawahana.

[16] Dally, H., 1983. Container Handling and Transport - A Manual of Current Practice. s.1.:London: Cargo.

[17] Law, A. \& Kelton, W., 1991. Simulation Modelling and Analysis. 2nd Edition. New York: McGraw-Hill.

[18] Huynh, N. N., Walton, C. M. \& River, R., 2005. Methodologies for Reducing Truck Turn Time at Marine Container Terminals Dalam: s.1.:Center for Transportation Research The University of Texas at Austin, pp. Vol. 7, No. 2, pp. 1-144.

[19] Andersen, B. \& Fagerhaug, T., 2006. Root cause analysis. simplified tools and techniques. s.1.:ASQ Quality Press.

[20] Snowdon, W., Schultz, J. \& Swinburn, B., 2008. Problem and solution trees: a practical approach for identifying potential interventions to improve population nutrition. Oxford University Press.

[20] Vis, I. F. \& Koster, R. d., 2002. Transshipment of containers at a container terminal: European Journal of Operational Research. 